\title{
Recycling Concrete Debris from Construction and Demolition Waste
}

\author{
Tomas U. Ganiron Jr \\ College of Architecture, Qassim University, Buraidah City \\ Asia-Pacific Chemical, Biological\& Environmental Engineering Society, \\ Hongkong \\ tomasuganironjr@gmail.com
}

\begin{abstract}
Recycling of concrete debris can make a contribution to reduce the total environmental impact of the building sector. To increase the scope for recycling in the future, aspects of recycling have to be included in the design phase. Besides, aggregate sources near Metro Manila are almost depleted, so aggregates have to be brought from far quarries. Consequently, reclaiming aggregates from concrete debris would lead to environmental and economic benefits. This experimental study aimed to use crushed concrete debris as alternative fine aggregate in a mortar mixture. A conventional mortar mixture will be compared to concrete debris mixture of the same proportions.
\end{abstract}

Keywords: Aggregate, concrete debris, construction material, mortar mixture, recycled waste

\section{Introduction}

Recycling as part of environmental considerations has become a common feature in the construction industry. Construction and demolition (C\&D) debris is the waste material that results from the construction, renovation, or demolition of any structure, including buildings, roads, and bridges.

Typical waste components include Portland cement concrete, asphalt concrete, wood, drywall, asphalt shingles, metal, cardboard, plastic, and soil. This waste material has only recently gained attention as concerns about its environmental impact have developed.

One of the things builders, developers and contractors must consider during construction, renovation or demolition is where to put all the debris. As what most people do in the preservation of the environment and for economic purposes, studies, researches and experiments are being done to discover new ways on how to find solution considering where else to put these debris and what can be done to lessen its disposal to landfills and since there is an increasing environmental problem regarding the waste disposal to landfills, it is necessary to think of possible ways on how to avoid these problems and at the same time secure safety and convenience, and that is, to recycle.

To fully understand the environmental implications of C\&D debris, it is important to understand the size of the C\&D debris stream. The exact quantity of $C \& D$ debris generated in the US is currently unknown. Many states do not track the amount of C\&D debris disposed of or recycled. Some states do collect this data from landfills and recycling facilities, but some facilities do not have scales and report only converted volume estimates [1,22]. Methodologies have been developed to estimate how much $\mathrm{C} \& \mathrm{D}$ debris is generated, generally applying average waste generation per unit area amounts to total area of construction, renovation, or demolition activity. Few other types of national C\&D debris estimations have been performed to find a better method or to contrast against the current estimations. A materials flow analysis is routinely used to 
estimate national municipal solid waste (MSW) generation and this method should be tested for the C\&D debris stream [2].

Recycling is often pursued as the most environmentally preferable method for managing C\&D debris. Finding a market for a recycled waste product is the most important step in establishing a recycling program. C\&D debris is not recycled in many areas of the US for varied reasons [3, 23]. One reason for the lack of recycling could be that markets for the recycled material do not exist. A market capacity analysis is needed to determine if there is sufficient demand for recycled materials to warrant $\mathrm{C} \& \mathrm{D}$ debris recycling programs $[4,24]$.

C\&D debris is typically disposed, recycled, or incinerated $[3,4]$. Because the states primarily regulate this waste stream and each state has different laws, it can be disposed in lined and unlined landfills depending on where it is disposed [4]. In a lined landfill, operators collect leachate from the landfill and either send it to a wastewater treatment plant or recirculate it in the landfill. In unlined landfills, the leachate escapes into the soil directly below the landfill, entering the environment. C\&D debris may be recycled at a recycling facility, where it replaces a natural resource or other competitive material in a new market. C\&D debris can be directly reused from the construction site [5, 25].

Due to the increasing demand for modern design of structures, as well as the problem with saving landfill spaces, this study paved the way to the recognition of using crushed concrete debris as substitute fine aggregate to mortar mix.

This study aimed to seek improvement in the production and allocation of good quality construction products out of recycled materials. It also aimed to develop a design mixture of recycled concrete debris as a mortar mix.

The result of this study will give the scholars and readers a new knowledge and the will to keep on learning and discovering new ways to make solutions to problems especially in the construction industry, particularly, on how to manage concrete debris, and at the same time promote hard work and perseverance in the pursuance of this career. This will also provide knowledge to the contractors and developers on how to improve the construction industry methods and services by using recycled concrete debris alternate fine aggregate in a mortar mix where they can achieve good product performance and meet recycling goals.

Moreover, the government will be able to find solutions to the problem regarding the disposal to landfills of these wastes materials and save the environment. They will visualize the potential of the recycled concrete debris as alternate fine aggregate to a mortar mix.

This study focused on designing concrete debris mixture that will meet the requirements of the ASTM for mortar mix. These include the (1) the mix proportion of concrete debris as mortar mixture, (2) the workability of the mixture in terms of consistency, mobility, and compactness as mortar, (3) the factors which affect the consistency and instability of the concrete debris mixture, and (3) the advantages and disadvantages of using concrete debris mixture mortar mix.

This study was limited to finding the compressive strength of the concrete debris mixture and the workability of the concrete debris mixture with an allowable penetration of $6.4 \mathrm{~mm}$, allowable compressive strength of 13.8 MPA, and 5in - 8in slump. This study was used as a basis in designing concrete debris mixture as mortar mix.

\section{Literature Review}

Recycling of waste concrete is done to reuse the concrete rubble as aggregates in concrete [6, 17]. The recycled aggregate have less crushing strength, impact resistance, specific gravity and has more absorption value as compared to fresh aggregates. Millions of tons of waste concrete are generated every year around the world due to following reasons [7, 8]: (a) Demolition of old structure. (b) 
Destruction of buildings and structures during earthquakes and wars. (c) Removal of useless concrete from structures, buildings, road pavements etc. (d) Waste concrete generated due to concrete cube and cylinder testing, destructive methods of testing of existing structures etc.

Products (aside from base course) are high quality aggregate, processed in steps with time and effort involved in crushing, pre-sizing, sorting, screening and contaminant elimination. The denominator is to start with clean; quality rubble in order to meet design criteria easily and ultimately yield a quality product that will go into end use shown in Figure 1[9].

Crushing and screening systems start with primary jaws, cones and/or large impactors taking rubble from 30 inches to 4 feet $[10,11]$. A secondary cone or impactor may or may not need to be run, and then primary and secondary screens may or may not be used, depending upon the project, the equipment used and the final product desired. A scalping screen will remove dirt and foreign particles. A fine harp deck screen will remove fine material from coarse aggregate $[12,13]$. Further cleaning is necessary to ensure the recycled concrete product is free of dirt, clay, wood, plastic and organic materials. This is done by water floatation, hand picking, air separators, and electromagnetic separators. Occasionally asphalt overlay or patch is found. A mixture of asphalt and concrete is not recommended but small patches are not detrimental. The more care that is put into the quality, the better product you will receive. With sound quality control and screening you can produce material without having to wash it as with virgin aggregate which may be ladened with clay and silt $[14,15]$.

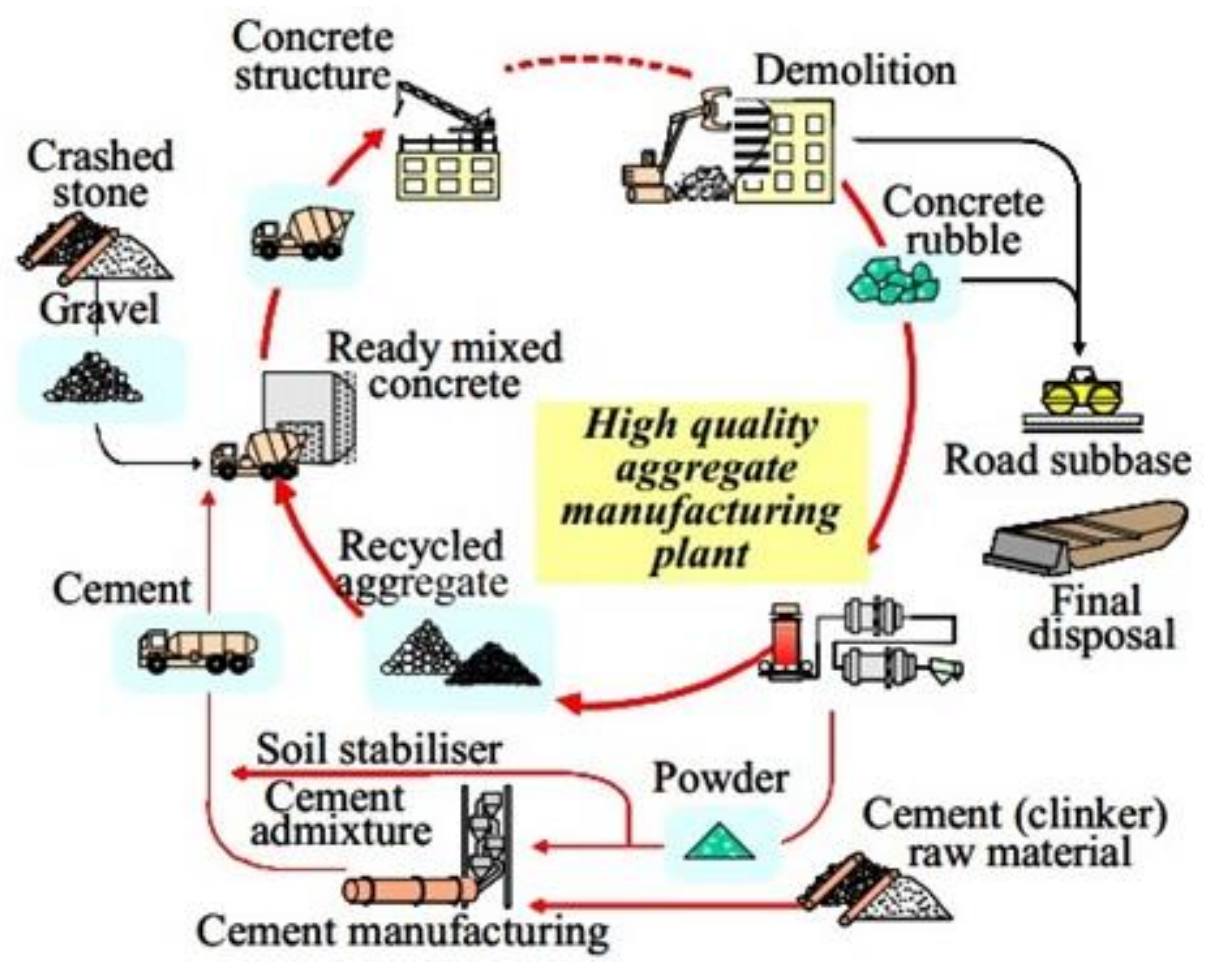

Figure 1. Process of Waste Concrete Recycling

Usually demolished concrete were shipped to landfills for disposal, but due to greater environmental awareness, the concrete is being recycled for reuse in concrete works. There are a variety of benefits in recycling concrete rather than dumping it or burying it in a landfill. Keeping concrete debris out of landfills saves space there. Other benefits of recycling of concrete are $[16,17]$ : (a) Local product - local sources. (b) 
Reduces truck traffic. (c) Alternative to a non-renewable resource. (d) Cost savings. (e) No disposal fees. (f) Better trucking utilization (reduced costs).

Using recycled material as gravel reduces the need for gravel mining. There are also economic benefits. Recycled concrete is a construction material that the community does not need to pay for; those who generated the concrete waste pay a fee to have it recycled $[18,26]$.

The strength of recycled aggregate concrete is about 10 to 15 per cent less as compared to concrete with fresh aggregate. However suitable mix designs may be made and reliable results obtained. The mix requires slightly higher quantity of cement or using admixtures to reduce water requirement. Recycled aggregate concrete can be safely used as plain concrete. With proper corrections in mix design, it can be used for R.C.C. works also.

There are no longer any regulatory or legal barriers to the use of recycled concrete as concrete aggregate. ASTM includes crushed hydraulic-cement concrete in its definition of concrete aggregates $[9,27]$.

The Federal Highway Administration and the U.S. Army Corps of Engineers has encouraged the use of recycled concrete in their projects [10,27]. Collection and sorting of construction debris is becoming a standard practice required by many states and municipalities. For example, authorities in Hawaii issued the publication, A Contractor's Waste Management Guide, which requires the use of recycled concrete and establishes policies and practices for managing waste materials [11, 23].

In Europe, Canada, and Japan, concrete recycling is regulated and often mandated. In particular, Germany promulgated the national setting the guidelines for recycled concrete content in concrete aggregate [12]. German researchers demonstrated that recycled aggregate does not affect most performance characteristics of concrete, although it tends to increase drying shrinkage and creep, and reduce modulus of elasticity [11, 12].

In Canada, the C-2000 Green Building Standards aim at making recyclable up to $75 \%$ of the existing structure and shell. However, this program does not require any processing of concrete other than separation from other demolition debris [13, 28]. In Japan, the draft standard for use of recycled concrete was published in 1977 [14, 20].

According to [15,29], Florida Statutes (F.S.), construction and demolition debris is currently defined as discarded materials generally considered to be not water-soluble and non-hazardous in nature, including, but not limited to, steel, glass, brick, concrete, asphalt roofing material, pipe, gypsum wallboard, and lumber, from the construction or destruction of a structure as part of a construction or demolition project or from the renovation of a structure, and including rocks, soils, tree remains, trees, and other vegetative matter that normally results from land clearing or land development operations for a construction project, including such debris from construction of structures at a site remote from the construction or demolition project site.

The North Carolina Solid Waste Management Act of 1989 requires that construction and demolition debris be separated from the waste stream and segregated at sanitary landfills $[16,21,22]$. To encourage recycling and reuse, regulations divide the waste stream into four categories: construction or demolition wastes, land-clearing wastes, inert wastes, and yard trash. They recommend the following methods for handling these materials: (a) construction and demolition debris should be separated into recyclable and non-recyclable material; (b) _inert debris (defined by the state as concrete, brick, concrete block, uncontaminated soil, rock, and gravel) should be recycled and reused as clean fill material; (c) yard trash and land-clearing debris should be reduced, reused, or recycled as mulch or compost $[17,23,30]$.

\section{Experimental Investigations}

This research utilized the experimental method with the use of the following tests: the sieve analysis, ball penetration test, slump test, and compression test in order to come up 
with a design mixture made up mainly of recycled concrete debris, water, and cement that will suit the requirements of the ASTM standards for mortar.

The researcher have examined the properties and factors, which affect the consistency, mobility, instability, and compactness of the conventional mortar mixture, which is made up of cement, sand and water, and the concrete debris mix, which is made up of cement, crushed concrete debris and water.

The provisions and specifications used were based from the ASTM, which was used as the basis of findings, conclusion and recommendations of this research.

\subsection{Project Design}

A flow chart is shown to fully illustrate the activities covered in this research. The following are the step-by-step procedures utilized in the design of the concrete debris mixture as mortar mix shown in Figure 2.

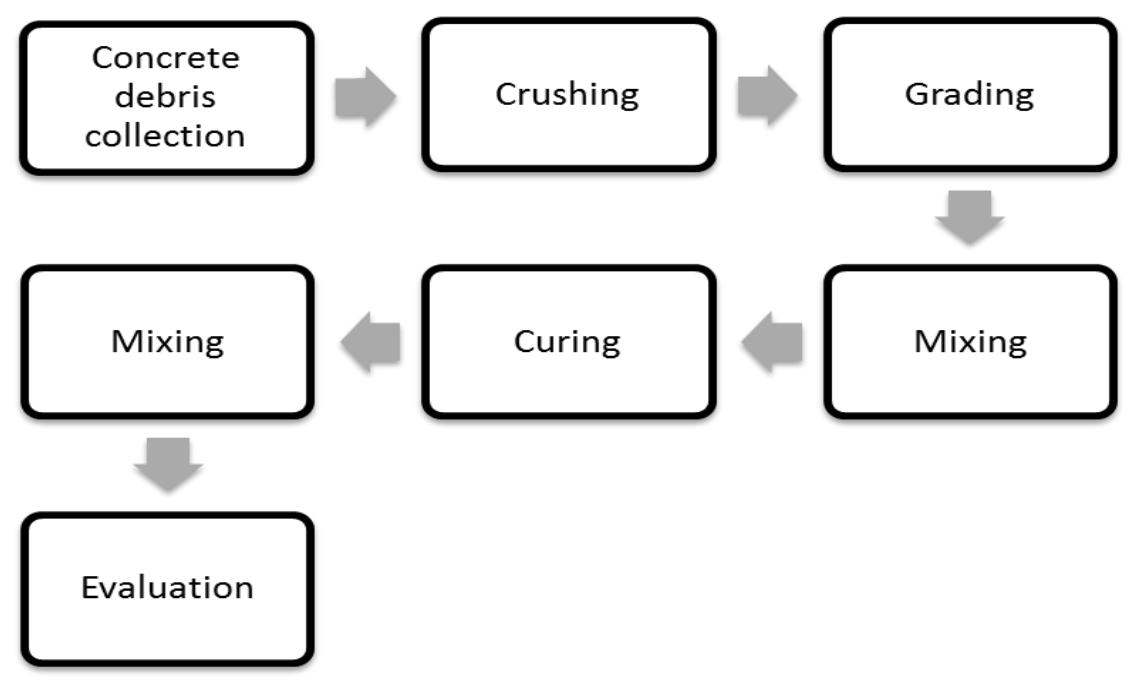

Figure 2. Project Design

As shown in Figure 2, the design of this research study includes the collection of concrete debris, crushing, grading, mixing, curing, testing, and evaluation.

The collected pieces of concrete debris are to be crushed and graded according to the ASTM required size of sand for masonry mortar with 100 percent passing the No. 4 sieve and 10 percent passing the No. 200 sieve. This is then mixed with cement and water in the ratio 1: 23/4: 61/4 (water, cement, and sand or crushed concrete debris respectively). Although there is no required mix proportion for mortar, the ratio of the materials mixed is stated according to what the tests specify. The provisions and specifications used were based from the ASTM, which was used as the basis of findings, conclusion and recommendations of this research.

The specimens were cured for 7, 14, 21, and 28 days until hydration is relatively completed and tested for compression. But for the specimens that were tested right after mixing, as for the ball penetration and slump tests, curing is not necessary.

The tests applied were the (1) ball penetration test, which determines the workability of the specimen, (2) slump test, which determines the plasticity or slump of the specimen, and (3) compression test, which determines the compressive strength of the specimen.

The results were then evaluated based on the tests applied on the specimens. This is whether the results passed or failed the standards of the ASTM for mortar. 


\subsection{Project Development}

A chart is shown in Figure 3 to illustrate the development of the project. This study was developed to help minimize the problem of the construction industry regarding the waste management, and material scarcity. The researcher considered these problems as the main reason for the purpose of this study.

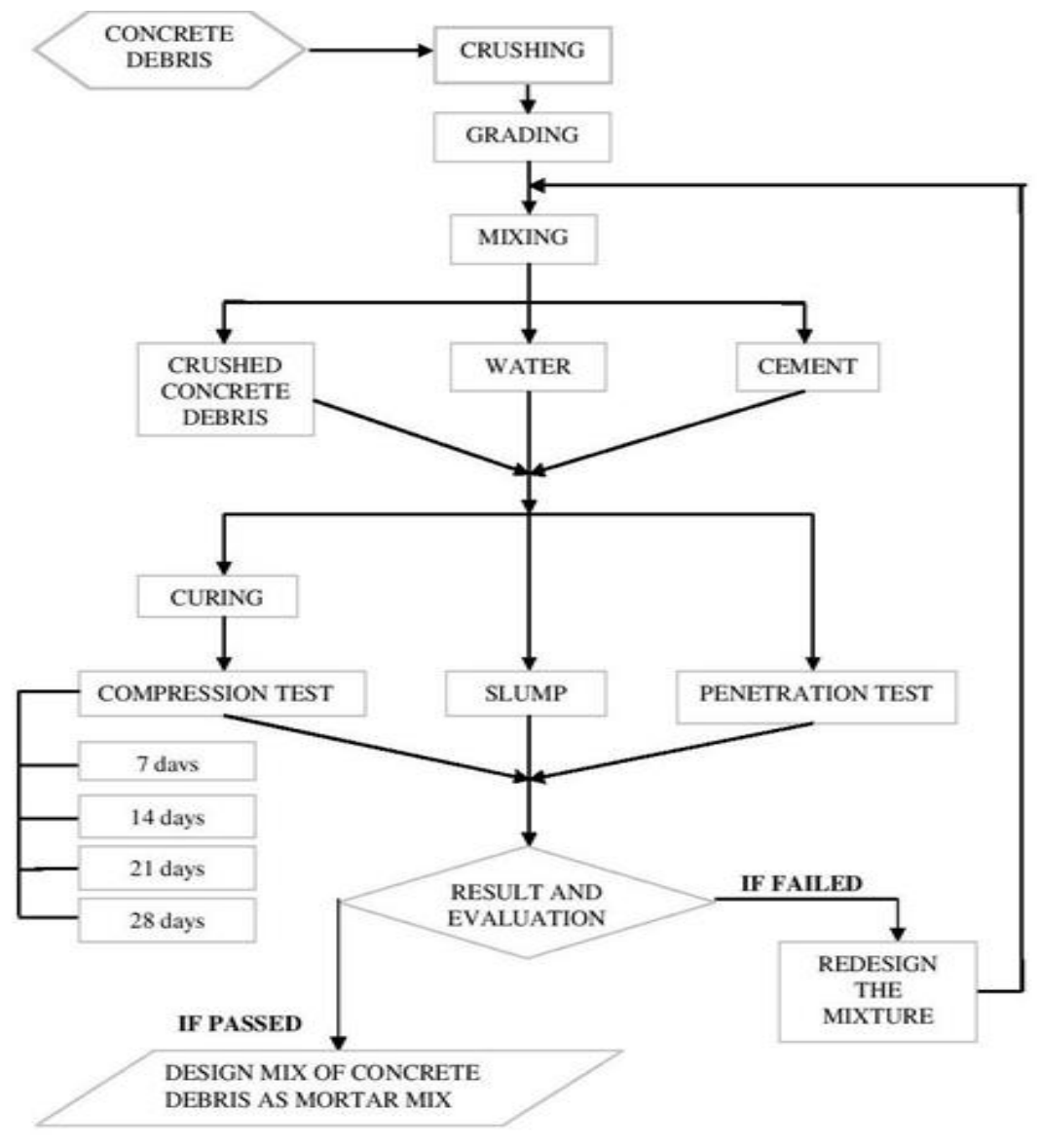

Figure 3. Project Development

In the development of this study, the researcher collected pieces of uncontaminated concrete debris from demolished residential structures. These pieces of debris were crushed manually using hammer and graded according to the Standard Specification for Sand for Masonry Mortar specified in ASTM C144, for manufactured sand, which is a 100 percent passing the No.4 sieve and10 percent passing the No.200 sieve. The graded crushed concrete debris was mixed with water and cement with 1:3 ratio of cement to crushed concrete debris. After three to five minutes of mixing a slump test was performed on the mixture with the addition of water until a desired flow was obtained, and five specimens were tested for penetration. Another five specimens for 7th, 14th, 21st, and 28 th day of curing were tested for compression test. A conventional mortar mix was als0 tested in the same manner. The results were evaluated whether the mixture failed or if it passed the standards for mortar. If it fails to meet the ASTM requirements; redesign the mixture, if it meets the ASTM requirements; then, adopt the design mixture.

\subsection{Operation and Testing Procedures}

The researcher considered these problems as the main reason for the purpose of this study. Experimentation and observations were the major basis of this research. 
Additional information and conditions from supplementary sources like the Internet, relevant books and articles, and most importantly the standard testing procedures of the American Standard for Testing and Materials (ASTM) were used.

This study was developed to help minimize the problem of the construction industry regarding the waste management, and material scarcity. The researcher considered these problems as the main reason for the purpose of this study. In order to come up with the output of this research, which is a design mixture of crushed concrete debris, various tests and experiments were made that served as the basis of this study and these are the following: (a) sieve analysis, (b) ball penetration test, (c) slump test and (d) compression test.

\subsection{Evaluation Procedures}

The methods used in this research study proved whether the recycled concrete debris material is acceptable or not, alternative fine aggregate in a mortar mix.

The compressive strength of mortar is sometimes used as a principal criterion for selecting mortar type, since compressive strength is relatively easy to measure, and it commonly relates to some other properties, such as tensile strength and absorption of the mortar. The compressive strength of mortar depends largely upon the cement content and the water-cement ratio. The accepted laboratory means for measuring compressive strength is to test 2 in. cubes of mortar. Because the referenced test in this specification is relatively simple, and because it gives consistent, reproducible results, compressive strength is considered a basis for assessing the compatibility of mortar ingredients. Field testing compressive strength of mortar is accomplished with Test Method C 780 using either 2 in. cubes or small cylindrical specimens of mortar. Perhaps because of the previously noted confusion regarding mortar and concrete the importance of compressive strength of mortar is over-emphasized.

Other mortar characteristics that influence general performance, such as aggregate grading, water retentivity and flow, can be accurately measured by laboratory tests and are included in ASTM Standards. Water retentivity allows mortar to resist the suction of dry masonry units and maintain moisture for proper curing. It is the mortar's ability to retain its plasticity in contact with absorptive masonry so that the mason can carefully align and level the units without breaking the bond.

Under laboratory conditions, water retention is measured by flow tests, and is expressed as the ratio of initial flow-to-flow suction. The flow test is similar to a concrete slump test, but is performed on a "flow table" that is rapidly vibrated up and down for several seconds.

Construction mortars require initial flow values on the order of 130 to $150 \%$. Laboratory mortars are required to have an initial flow of 100 to $115 \%$. Experienced masons quickly and accurately adjust the amount of mixing water required to produce good workability, proper flow, and water retention.

Mortar normally begins to harden or set about 2.5 hours after initial mixing. After this point, retempering will decrease compressive strength by approximately $25 \%$. ASTM standards require that all mortar be used within 2.5 hours and permit retempering as frequently as needed within this time period.

Tests have shown that the decrease in compressive strength is minimal if retempering occurs only 1 to 2 hours after mixing. Mortar that is not used within 2.5 hours or that has begun to set should be discarded. 


\section{Results and Discussions}

\subsection{Mix Proportion of the Specimen}

For compression and penetration tests, $24 \%$ cement, $11 \%$ water, and $65 \%$ crushed concrete debris make up the mortar mix (refer to Figure 4). For the slump test, the amount of water is increased from $11 \%$ to $60 \%$ due to the need to find the slump of the mixture. The amount of the concrete debris is now $29 \%$ and cement is $11 \%$ (refer to Figure 5).

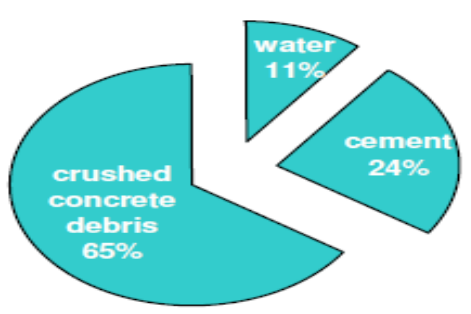

$\square$ water $\square$ cement $\square$ crushed concrete debris

Figure 4. Concrete Debris Mix Proportion of 2-in Cube Specimen

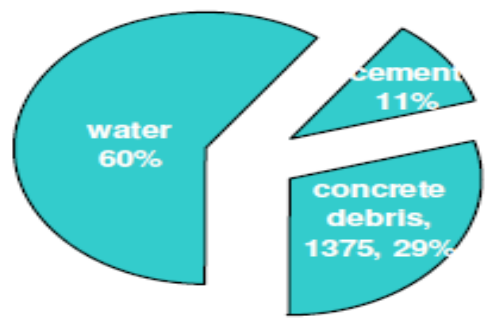

$\square$ water $\square$ cement $\square$ concrete debris

Figure 5. Concrete Debris Mix Proportion of Slump Specimen

As shown in Figure 6, the amount of water and cement are plotted to find the effect of the mix proportion in the cementitious material. These values were obtained by using ratio and proportion.

Based from the values shown, the amount of water for every $250 \mathrm{~g}$ of concrete debris is $36.36 \mathrm{~g}$ and cement is $90.90 \mathrm{~g}$. This is applicable for 2-in cube specimens used for compression and penetration tests.

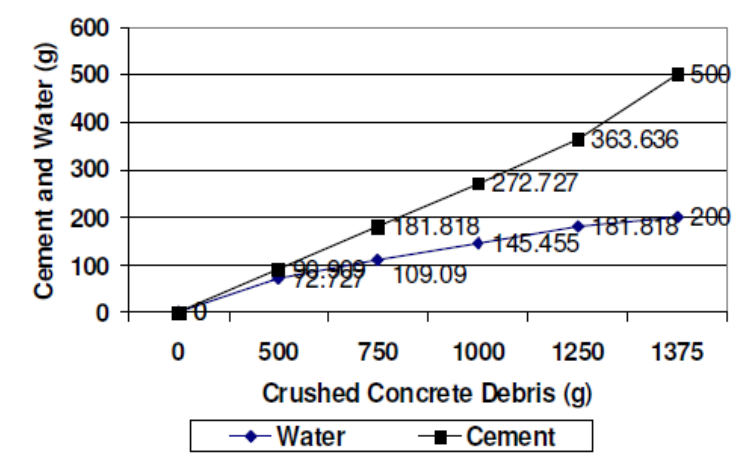

Figure 6. Water and Cement Ratio to Concrete Debris 


\subsection{Sieve Analysis}

Table 1 shows the result of the graded crushed concrete debris using sieve analysis according to the ASTM C144, standard specification for sand and masonry mortar with $100 \%$ passing the No. 4 sieve and 10\% passing the No. 200 sieve.

\section{Table 1. Sieve Analysis of Crushed Concrete Debris}

\begin{tabular}{|c|c|c|c|c|c|}
\hline \multirow{2}{*}{$\begin{array}{c}\text { Sieve Size } \\
(\mathrm{mm})\end{array}$} & \multirow{2}{*}{$\begin{array}{c}\text { Mass } \\
\text { Retained (g) }\end{array}$} & \multicolumn{3}{|c|}{ Cumulative } & \multirow{2}{*}{$\begin{array}{l}\text { Specification, } \\
\text { \% passing }\end{array}$} \\
\hline & & $\begin{array}{l}\text { Mass Passing } \\
\text { (g) }\end{array}$ & \% Passing & \% Retained & \\
\hline 4.750 & 9.76 & 1365.24 & 99.29 & 0.71 & 100 \\
\hline 2.360 & 59.63 & 1305.61 & 95.63 & 4.37 & $95-100$ \\
\hline 1.180 & 94.67 & 1210.94 & 92.74 & 7.26 & $70 \cdot 100$ \\
\hline 0.600 & 386.14 & 824.80 & 68.11 & 6.89 & 40.75 \\
\hline 0.300 & 528.36 & 296.44 & 35.94 & 4.06 & $20 \cdot 40$ \\
\hline 0.150 & 234.82 & 61.62 & 20.79 & 4.21 & $10-25$ \\
\hline 0.075 & & & 1.00 & 9.00 & $0-10$ \\
\hline Pan & 61.62 & & & & \\
\hline Total & 1375.00 & & & & \\
\hline
\end{tabular}

\subsection{Penetration Test of Standard and Concrete Debris Mix}

Table 2 shows the different values of penetration of each five specimens of the two mixtures.

\section{Table 2. Sieve Analysis of Crushed Concrete Debris}

\begin{tabular}{|c|c|c|c|}
\hline Standard Mix & $\begin{array}{c}\text { Penetration } \\
(\mathrm{mm})\end{array}$ & $\begin{array}{c}\text { Concrete } \\
\text { Debris Mix }\end{array}$ & $\begin{array}{c}\text { Penetration } \\
(\mathrm{mm})\end{array}$ \\
\hline 1 & 3.8 & 1 & 4.0 \\
\hline 2 & 5.0 & 2 & 5.5 \\
\hline 3 & 4.5 & 3 & 5.9 \\
\hline 4 & 5.0 & 4 & 5.0 \\
\hline 5 & 4.0 & 5 & 4.0 \\
\hline Average & 4.46 & Average & 4.88 \\
\hline
\end{tabular}

The average difference of the penetration of the standard mix is $8.61 \%$ higher than the average penetration of the concrete debris mixture. However, the penetration must be read from the nearest $1 / 4$ in $(6.4 \mathrm{~mm})$. Hence, the penetration of the concrete debris mixture passed the allowed penetration for mortar.

\subsection{Slump of Standard and Concrete Mix}

As shown in Table 3, the slump of standard mix is 7.2 inches while concrete debris mix has a slump of 7.3 inches. In this test, the difference of slump values is only $0.1 \mathrm{inch}$. However, the slumps of the two mixtures were obtained with the addition of water from $11 \%$ to $60 \%$. The required slump for mortar is from $5-8$ inches. Therefore, the slump of the concrete debris mixture passed the required slump for mortar.

Table 3. Slump of Standard and Concrete Mix

\begin{tabular}{|c|c|}
\hline \begin{tabular}{|c|}
\hline Slump of Standard Mix \\
(in)
\end{tabular} & Slump of Concrete Debris Mix \\
\hline 7.2 & 7.3 \\
\hline
\end{tabular}


Figure 7 shows the slump of different materials. The slump of concrete is 2 to 6 inches, while mortar is 5 to 8 inches and grout has 8 to 10 inches.

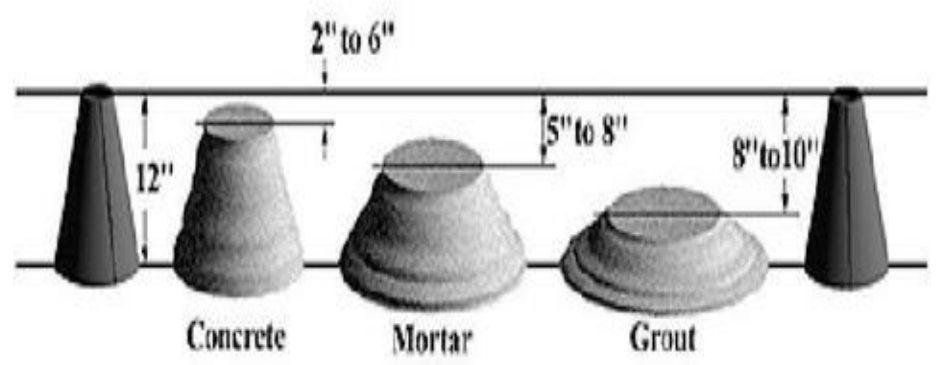

Figure 7. Slump of Different Materials

\subsection{Compression Test}

The values shown in Table 4 are the weight $(\mathrm{g})$, maximum load capacity $(\mathrm{KN})$, and the compression strength (MPa) of each five specimens of equal areas of both standard and concrete debris mixtures.

Table 4. Standard and Concrete Debris Mix (7 days)

\begin{tabular}{|c|c|c|c|c|}
\hline $\begin{array}{l}\text { No. of Standard } \\
\text { Mix Specimen }\end{array}$ & $\begin{array}{c}\text { Area } \\
\left(\mathrm{mm}^{2}\right)\end{array}$ & $\begin{array}{l}\text { Wt } \\
(\mathrm{g})\end{array}$ & $\begin{array}{l}\text { Load } \\
(\mathrm{Kn})\end{array}$ & $\begin{array}{c}\text { Compressive } \\
\text { Strength (Mpa) }\end{array}$ \\
\hline 1 & 2500 & 275.4 & 44.78 & 17.91 \\
\hline 2 & 2500 & 278 & 51.88 & 20.72 \\
\hline 3 & 2500 & 279 & 35.57 & 14.23 \\
\hline 4 & 2500 & 266 & 54.67 & 21.87 \\
\hline 5 & 2500 & 267 & 31.84 & 12.73 \\
\hline Average & & & & 17.492 \\
\hline $\begin{array}{l}\text { No. of Concrete } \\
\text { Debris Mix } \\
\text { Specimen }\end{array}$ & $\begin{array}{c}\text { Area } \\
\left(\mathrm{mm}^{2}\right)\end{array}$ & $\begin{array}{l}\text { Wt } \\
(\mathrm{g})\end{array}$ & $\begin{array}{l}\text { Load } \\
(\mathrm{Kn})\end{array}$ & $\begin{array}{c}\text { Compressive } \\
\text { Strength (Mpa) }\end{array}$ \\
\hline 1 & 2500 & 252 & 28.44 & 11.38 \\
\hline 2 & 2500 & 245.8 & 24.58 & 9.83 \\
\hline 3 & 2500 & 252.8 & 31.39 & 12.53 \\
\hline 4 & 2500 & 237.5 & 24.77 & 9.99 \\
\hline 5 & 2500 & 244.8 & 33.31 & 13.33 \\
\hline Average & & & & 11.412 \\
\hline
\end{tabular}

The values shown in Table 5 are the weight $(\mathrm{g})$, maximum load capacity $(\mathrm{KN})$, and the compression strength (MPa) of each five specimens of equal areas of both standard and concrete debris mixtures. This time, the average compressive strength of the standard mix is $10.20 \%$ stronger than the average compressive strength of the concrete debris mixture cured for 14 days. However, the average of both mixtures is above the allowable compressive strength of mortar with the concrete debris mixture $2.725 \%$ higher than the allowable. 
Table 5. Standard and Concrete Debris Mix (14 days)

\begin{tabular}{|c|c|c|c|c|c|}
\hline $\begin{array}{c}\text { No. of Standard } \\
\text { Mix Specimen }\end{array}$ & $\begin{array}{c}\text { Area } \\
\left(\mathrm{mm}^{2}\right)\end{array}$ & $\begin{array}{c}\text { Wt } \\
(\mathrm{g})\end{array}$ & $\begin{array}{c}\text { Load } \\
(\mathrm{Kn})\end{array}$ & $\begin{array}{c}\text { Compressive } \\
\text { Strength (Mpa) }\end{array}$ \\
\hline 1 & 2500 & 303 & 39.87 & 15.95 \\
\hline 2 & 2500 & 310.4 & 34.62 & 13.85 \\
\hline 3 & 2500 & 305.8 & 40.84 & 16.34 \\
\hline 4 & 2500 & 309.4 & 39.7 & 15.88 \\
\hline 5 & 2500 & 299.4 & 42.26 & 16.91 \\
\hline Average & & & & 15.786 \\
\hline $\begin{array}{c}\text { No. of Concrete } \\
\text { Debris Mix }\end{array}$ & $\begin{array}{c}\text { Area } \\
\text { Specimen }\end{array}$ & Wt & Load & Compressive \\
\hline 1 & 2500 & 300.8 & 38.44 & 15.38 \\
\hline 2 & 2500 & 280 & 33.81 & 13.52 \\
\hline 3 & 2500 & 285.3 & 39.56 & 15.82 \\
\hline 4 & 2500 & 288 & 32.25 & 12.90 \\
\hline 5 & 2500 & 273 & 33.14 & 13.26 \\
\hline \hline Average & & & & 14.176 \\
\hline
\end{tabular}

As shown in Table 6, the average compressive strength of the standard mix at this time is only $8.40 \%$ stronger than the average compressive strength of the concrete debris mixture cured for 21 days. Hence, both the average compressive strengths of the two mixtures are above the allowable compressive strength with the concrete debris mix having $18.015 \%$ higher than the allowable.

Table 6. Standard and Concrete Debris Mix (21 days)

\begin{tabular}{|c|c|c|c|c|}
\hline $\begin{array}{l}\text { No. of Standard } \\
\text { Mix Specimen }\end{array}$ & $\begin{array}{c}\text { Area } \\
\left(\mathrm{mm}^{2}\right)\end{array}$ & $\begin{array}{l}\text { Wt } \\
(\mathrm{g})\end{array}$ & $\begin{array}{l}\text { Load } \\
(\mathrm{Kn})\end{array}$ & $\begin{array}{l}\text { Compressive } \\
\text { Strength (Mpa) }\end{array}$ \\
\hline 1 & 2500 & 290.5 & 36.25 & 14.50 \\
\hline 2 & 2500 & 263.6 & 39.58 & 15.83 \\
\hline 3 & 2500 & 310.8 & 49.67 & 19.87 \\
\hline 4 & 2500 & 307.5 & 46.59 & 18.64 \\
\hline 5 & 2500 & 302.0 & 50.15 & 20.06 \\
\hline Average & & & & 17.78 \\
\hline $\begin{array}{l}\text { No. of Concrete } \\
\text { Debris Mix } \\
\text { Specimen }\end{array}$ & $\begin{array}{c}\text { Area } \\
\left(\mathrm{mm}^{2}\right)\end{array}$ & $\begin{array}{l}\text { Wt } \\
(\mathrm{g})\end{array}$ & $\begin{array}{l}\text { Load } \\
(\mathrm{Kn})\end{array}$ & $\begin{array}{l}\text { Compressive } \\
\text { Strength (Mpa) }\end{array}$ \\
\hline 1 & 2500 & 259 & 37.72 & 15.09 \\
\hline 2 & 2500 & 269 & 45.34 & 18.14 \\
\hline 3 & 2500 & 296.2 & 50.33 & 20.13 \\
\hline 4 & 2500 & 260 & 33.52 & 13.41 \\
\hline 5 & 2500 & 263 & 36.66 & 14.66 \\
\hline Average & & & & 16.286 \\
\hline
\end{tabular}

The values shown in Table 7 are the weight (g), maximum load capacity (KN), and the compression strength (MPa) of each five specimens of equal areas of both standard and concrete debris mixtures. This time the average compressive strength of the standard mix is $17.50 \%$ stronger than the average compressive strength of the 
concrete debris mixture cured for 28 days reaching about $43.91 \%$ higher than the allowable compressive strength of mortar. However, the average compressive strength of the concrete debris mixture this time is $18.72 \%$ higher than the allowable compressive strength.

\section{Table 7. Standard and Concrete Debris Mix (28 days)}

\begin{tabular}{|c|c|c|c|c|}
\hline $\begin{array}{l}\text { No. of Standard } \\
\text { Mix Specimen }\end{array}$ & $\begin{array}{l}\text { Area } \\
\left(\mathrm{mm}^{2}\right)\end{array}$ & $\begin{array}{l}\text { Wt } \\
(\mathrm{g})\end{array}$ & $\begin{array}{l}\text { Load } \\
(\mathrm{Kn})\end{array}$ & $\begin{array}{l}\text { Compressive } \\
\text { Strength (Mpa) }\end{array}$ \\
\hline 1 & 2500 & 311.2 & 49.85 & 19.94 \\
\hline 2 & 2500 & 292.8 & 57.16 & 22.87 \\
\hline 3 & 2500 & 328.2 & 50.64 & 20.25 \\
\hline 4 & 2500 & 313.3 & 42.25 & 16.98 \\
\hline 5 & 2500 & 287 & 48.15 & 19.26 \\
\hline Average & & & & 19.86 \\
\hline $\begin{array}{l}\text { No. of Concrete } \\
\text { Debris Mix } \\
\text { Specimen }\end{array}$ & $\begin{array}{c}\text { Area } \\
\left(\mathrm{mm}^{2}\right)\end{array}$ & $\begin{array}{l}\text { Wt } \\
(\mathrm{g})\end{array}$ & $\begin{array}{l}\text { Load } \\
(\mathrm{Kn})\end{array}$ & $\begin{array}{l}\text { Compressive } \\
\text { Strength (Mpa) }\end{array}$ \\
\hline 1 & 2500 & 285.8 & 46.70 & 18.68 \\
\hline 2 & 2500 & 285 & 41.07 & 18.83 \\
\hline 3 & 2500 & 290 & 35.13 & 14.05 \\
\hline 4 & 2500 & 264.2 & 39.50 & 15.80 \\
\hline 5 & 2500 & 280.3 & 36.39 & 14.56 \\
\hline Average & & & & 16.384 \\
\hline
\end{tabular}

Figure 7 shows the variation of the average stresses of the standard mix and the concrete debris mixture, which were both cured for 7, 14, 21, and 28 days. The highest average compressive strength for each mixture was obtained on the 28th day of curing. It shows that the standard mortar mixture results to an average compressive stress of $17.61 \%$ higher than the concrete debris mixture on the 28th day. However, the average compressive strength of the concrete debris mix is above the allowable compressive strength of mortar.

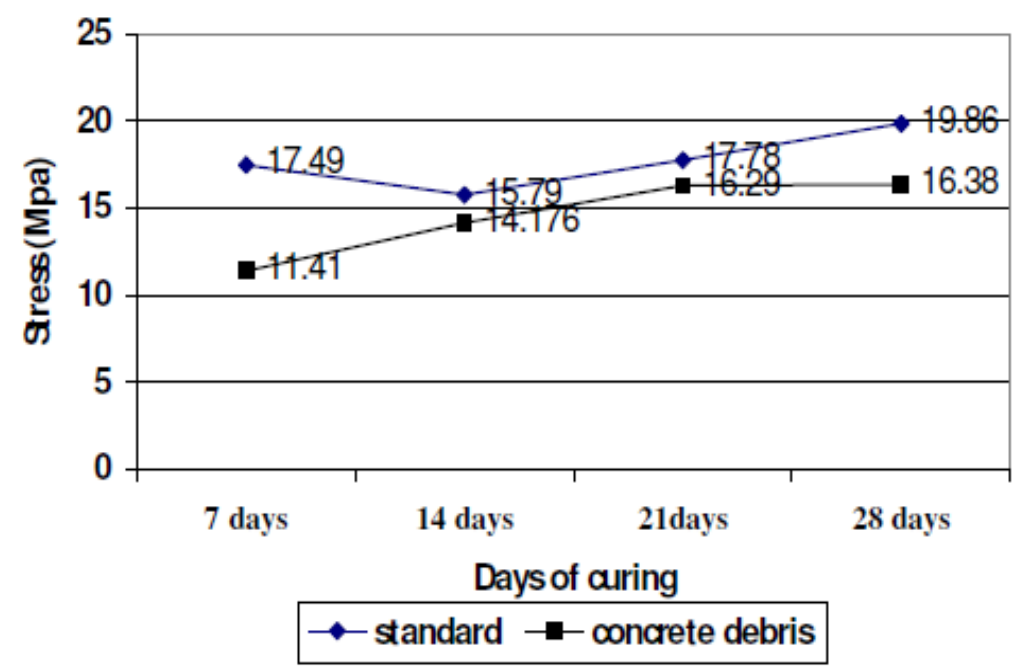

Figure 7. Average Compressive Strength of Standard and Concrete Debris Mix 
As shown in Table 8, the compressive strength at 28th day of a cement-sandgravel mixed with 1:3:6 ratios are $13.8 \mathrm{MPa}$, and the cement-concrete debris-water mix with ratio of $1: 23 / 4: 61 / 4$. The compressive strength is $16.384 \mathrm{MPa}$ at 28th days.

Table 8. Compressive Strength at 28th Day of CSG Mix and CSW Mortar Mix

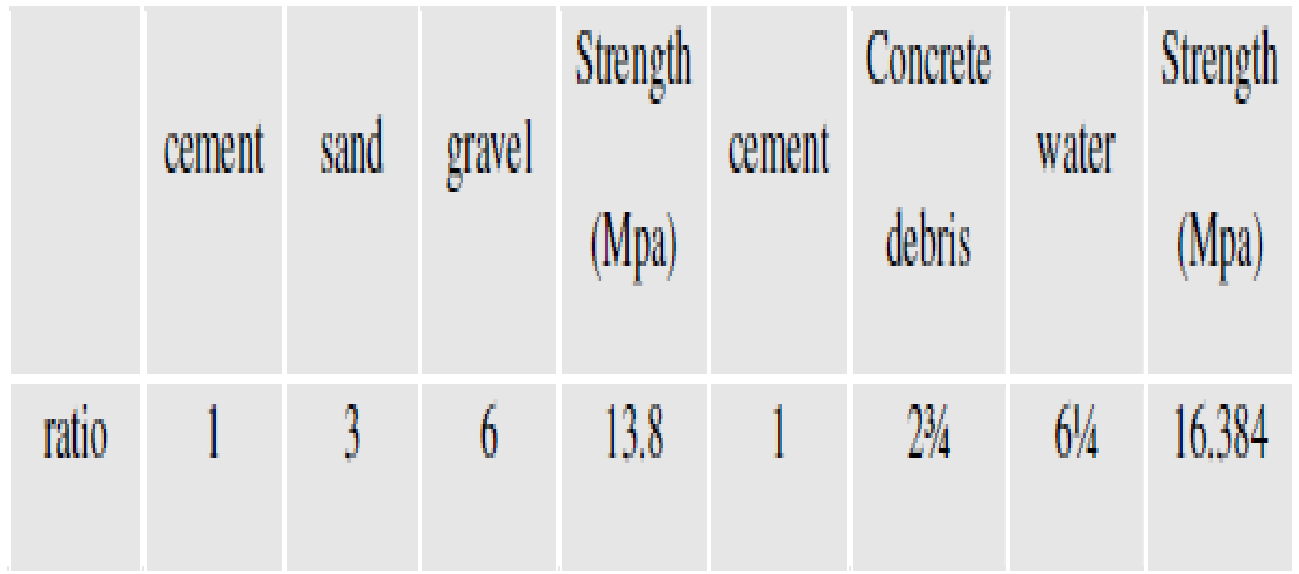

\subsection{Cost Analysis}

Table 9 shows the estimated cost between the standard mortar mix and the concrete debris mix. The total amount shown for the use of crushed concrete debris is just an estimate of the demolition activity, (the cost of the crushed concrete debris is not yet included), and the values show that the standard mortar mix(including labor and material costs) is cheaper than the crushed concrete debris mix.

Table 9. Cost Analysis

\begin{tabular}{|c|c|c|c|c|c|}
\hline Unit & $\begin{array}{c}\text { Standard } \\
\text { Mix }\end{array}$ & $\begin{array}{c}\text { Price } \\
\text { (Estimated) }\end{array}$ & Unit & $\begin{array}{l}\text { Concrete } \\
\text { Debris Vix }\end{array}$ & $\begin{array}{c}\text { Price } \\
\text { (Esimated) }\end{array}$ \\
\hline 40k-bag & cement & P175.00 & 40k-bag & cement & P175.00 \\
\hline Cu. m. & sand & P500,00 & Sq. m. & $\begin{array}{l}\text { Crushed } \\
\text { concrete } \\
\text { debris }\end{array}$ & P95.00 \\
\hline $\begin{array}{l}\text { Total } \\
\text { Price }\end{array}$ & & P186600lss, m. & $\begin{array}{l}\text { Total } \\
\text { Price }\end{array}$ & & P163.00/sq, m. \\
\hline
\end{tabular}


Table 10. Potential Uses for Materials Commonly Found in Concrete Debris

\begin{tabular}{|c|c|}
\hline Material & Potential Use \\
\hline asphalt & road sub-base fill \\
\hline concrete & $\begin{array}{l}\text { Crushed and mixed to make new asphalt cement blocks; } \\
\text { crushed and screened aggregate can be used in asphaltic concrete }\end{array}$ \\
\hline dirt & Landscaping landfill cover \\
\hline metal & Scrap metal dealers \\
\hline wood & $\begin{array}{l}\text { Timber/wood pulp: shredded for fuel, animal bedding, landscaping, } \\
\text { manufactured building products, and compost }\end{array}$ \\
\hline brick & Masonry crushed for ornamental stone \\
\hline glass & Fiberglass insulation, sand blast, aggregate in asphalt reflective beads \\
\hline gypsum & Soil amendment, gypsum board, absorbent media \\
\hline plastic & $\begin{array}{l}\text { ABS: plastic lumber } \\
\text { PVC: highway barriers } \\
\text { Polyethylene: traffic cones }\end{array}$ \\
\hline polystyrene & Insulation \\
\hline porcelain & Crushed for aggregate \\
\hline $\begin{array}{l}\text { corrugated } \\
\text { cardboard }\end{array}$ & Paper mills, fuel pellets \\
\hline carpet & Landfill cover \\
\hline roofing shingles & Asphalt paving \\
\hline
\end{tabular}

\subsection{Use of Concrete Debris}

Table 10 shows the potential uses of materials that are commonly found in construction and demolition debris. It shows that concrete debris, when crushed can be mixed with new asphalt cement blocks; crushed and graded aggregates can be used in asphaltic concrete, while bricks are crushed for ornamental stones.

\subsection{Mix Applications}

Table 11 shows the nominal mix proportions by volume for common applications. For mortar, which is applied for general use and in bricklaying, the proportion by volume of cement to building sand is 1 part: 5 parts where $300 \mathrm{~kg}$ of cement per $\mathrm{m} 3$ (approximately), is 67 building sand bags. 
Table 11. Mix Applications

\begin{tabular}{|c|c|c|c|}
\hline \multirow{7}{*}{ CONCRETE } & Applications & $\begin{array}{c}\text { Proportions by } \\
\text { volume }\end{array}$ & $\begin{array}{c}\text { Amount per } \mathrm{m}^{3} \\
\text { (approx.) }\end{array}$ \\
\hline & \multirow{2}{*}{$\begin{array}{l}\text { General Purpose } \\
\text { Concrete }\end{array}$} & $\begin{array}{l}1 \text { part cement: } 2 \\
\text { parts sharp sand: } 3 \\
\text { parts } 20 \mathrm{~mm} \text { gravel }\end{array}$ & $\begin{array}{l}325 \mathrm{~kg} \text { cement: } 30 \\
\text { bags sharp sand: } 44 \\
\text { bags } 20 \mathrm{~mm} \text { gravel }\end{array}$ \\
\hline & & $\begin{array}{l}1 \text { part cement: } 4 \\
\text { parts } 20 \mathrm{~mm} \text { ballast }\end{array}$ & $\begin{array}{l}375 \mathrm{~kg} \text { cement : } 70 \\
\text { bags } 20 \mathrm{~mm} \text { ballast }\end{array}$ \\
\hline & Paving/Driveways & $\begin{array}{l}1 \text { part cement: } 1 \frac{1}{2} \\
\text { parts sharp sand : } 2 \\
1 / 2 \text { parts } 20 \mathrm{~mm} \\
\text { gravel }\end{array}$ & $\begin{array}{l}375 \mathrm{~kg} \text { cement : } 26 \\
\text { bags sharp sand: } 44 \\
\text { bags } 20 \mathrm{~mm} \text { gravel }\end{array}$ \\
\hline & $\begin{array}{l}\text { Fine Concrete- } \\
\text { (Garden steps, paths, } \\
\text { etc.) }\end{array}$ & $\begin{array}{l}1 \text { part cement: } 21 / 2 \\
\text { parts sharp sand: } 31 / 2 \\
\text { parts } 20 \mathrm{~mm} \text { gravel }\end{array}$ & $\begin{array}{l}300 \text { g cement: } 25 \\
\text { bags sharp sand: } 50 \\
\text { bags } 10 \mathrm{~mm} \text { gravel }\end{array}$ \\
\hline & $\begin{array}{c}\text { Foundations- } \\
\text { Footings, } \\
\text { foundations, shed }\end{array}$ & $\begin{array}{l}1 \text { part cement- } 21 / 2 \\
\text { parts sharp sand: } 3 \\
1 / 2 \text { parts } 20 \mathrm{~mm} \\
\text { gravel }\end{array}$ & $\begin{array}{l}300 \mathrm{~kg} \text { cement: } 31 \\
\text { bags sharp sand: } 44 \\
\text { bags } 20 \mathrm{~mm} \text { gravel }\end{array}$ \\
\hline & bases etc.) & $\begin{array}{l}1 \text { part cement: } 5 \\
\text { parts } 20 \mathrm{~mm} \text { ballast }\end{array}$ & $\begin{array}{l}325 \mathrm{~kg} \text { cement: } 74 \\
\text { bags } 20 \mathrm{~mm} \text { ballast }\end{array}$ \\
\hline & Applications & $\begin{array}{l}\text { Proportions by } \\
\text { volume }\end{array}$ & $\begin{array}{l}\text { Amount per } \mathrm{m} 3 \\
\text { (approx.) }\end{array}$ \\
\hline MORTAR & $\begin{array}{c}\text { General use, } \\
\text { bricklaying and } \\
\text { repointing }\end{array}$ & $\begin{array}{l}1 \text { part cement: } 5 \\
\text { parts building sand }\end{array}$ & $\begin{array}{l}300 \mathrm{~kg} \text { cement: } 67 \\
\text { building sand bags }\end{array}$ \\
\hline & Render (First coat) & $\begin{array}{l}1 \text { part cement: } 3 \frac{1}{2} \\
\text { parts building sand }\end{array}$ & $\begin{array}{l}400 \mathrm{~kg} \text { cement: } 67 \\
\text { building sand bags }\end{array}$ \\
\hline & Floor screeds & $\begin{array}{l}1 \text { part cement: } 31 / 2 \\
\text { parts sharp sand }\end{array}$ & $\begin{array}{l}400 \mathrm{~kg} \text { cement: } 67 \\
\text { building sand bags }\end{array}$ \\
\hline
\end{tabular}

\section{Conclusion}

Concrete is the only material that does not face substantial competition from other recycled materials. Its main competitor is crushed stone, which is plentiful. Many provinces of the Philippines, however, do not produce crushed stone but do have a need for aggregates that could be replaced by recycled concrete. Thus, there is sufficient capacity to recycle all of the concrete generated. Environmentally, recycling concrete is the preferred method of management in most areas of Metro Manila. Due to the proximity of limestone mines and distance of recycling facilities or landfill may be preferable in some areas. Based from the observations on the experiments performed, the researcher concludes the following: (a) The proportions of the crushed concrete debris affects cement and water in a manner that it absorbs most of the water in the mixture. (b) The concrete debris mixture obtained a high slump and low compressive strength at its seventh day of curing. (c) The amount of water in the mixture affects the consistency of the mortar mixture. (d) The concrete debris mix, with 1:3 ratio of cement to crushed concrete debris with considerable slump and penetration, has an acceptable mobility as the standard mortar mix of the same cement to sand ratio. (e)The concrete debris having 1:23/4 cement to crushed concrete debris ratio of 2 -in cubes is as compact as the standard mortar mix of the same cement to sand ratio and (f) Its' mix proportion affects the consistency or workability of a mortar mix having 1:23/4 cement to crushed concrete debris ratio. 


\section{Appendix}

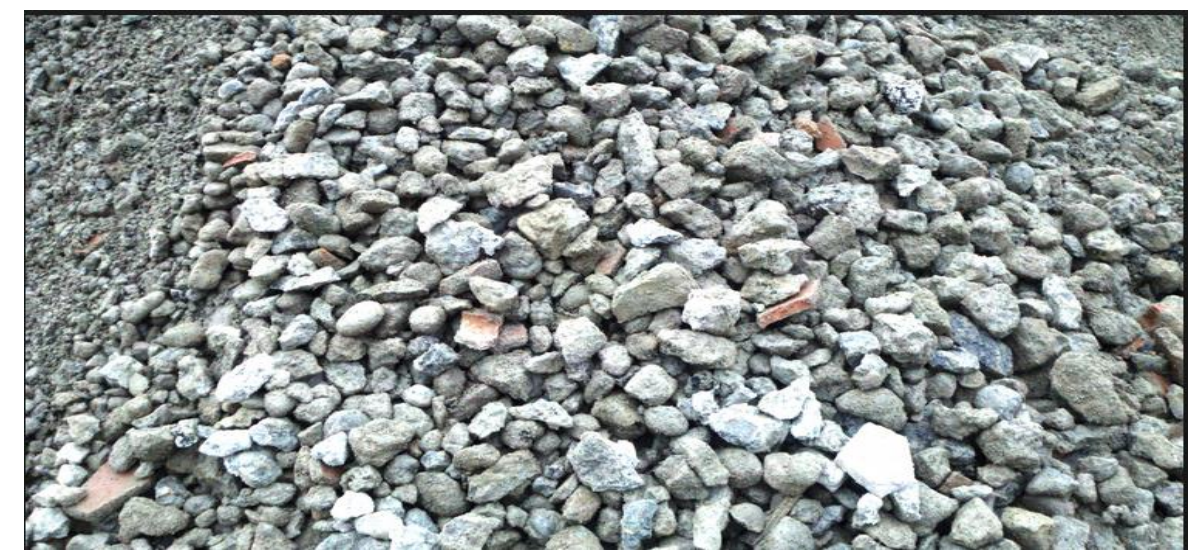

Figure 8. Concrete Debris from Landfills

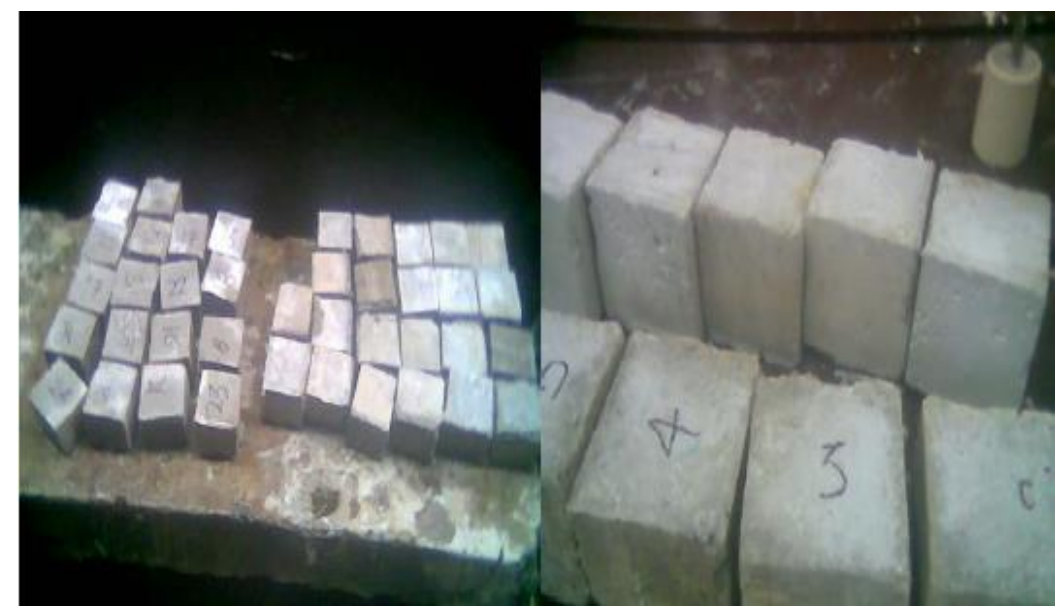

Figure 9. Concrete in Cube Specimens

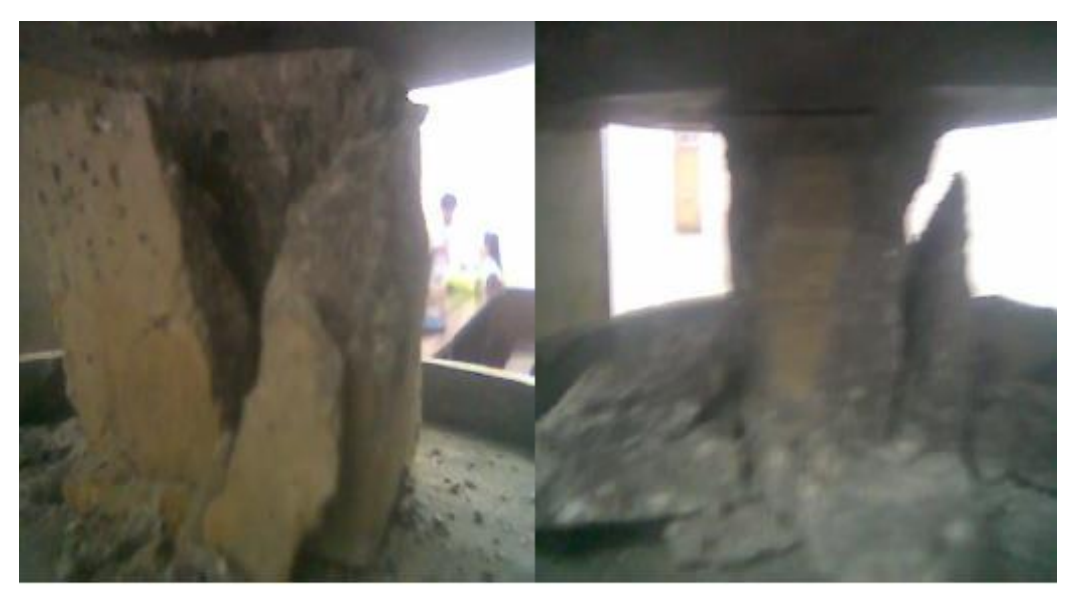

Figure 10. Specimens after Compression Tests 


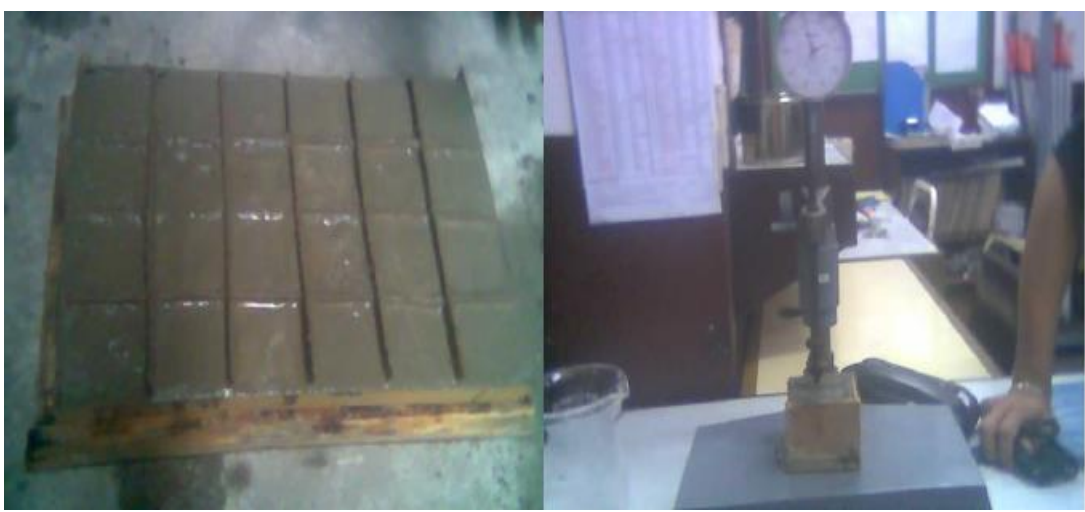

Figure 11. Specimens for Penetration Tests

\section{References}

[1] T. U. Ganiron Jr., "Recycled window glass for non-load bearing walls", International Journal of Innovation, Management and Technology, vol. 3, no. 6, (2012), pp. 725-730.

[2] T. U. Ganiron, Jr., "Investigation on the use of pleko ceiling board for heat insulator and sound proofing material applications", International Journal of Advanced Science and Technology, vol. 65, (2014), pp. 23-32.

[3] F. Ackerman and K. Gallagher, "Mixed signals: Market incentives, recycling, and the price spike of 1995", Resources, Conservation and Recycling, vol. 30, no. 4, (2002), pp. 275-295.

[4] T. U. Ganiron, Jr., "Influence of polymer fiber on strength of concrete", International Journal of Advanced Science and Technology, vol. 55, (2013), pp. 53-66.

[5] T. U. Ganiron, Jr., "Effects of human hair additives in compressive strength of asphalt cement mixture", International Journal of Advanced Science and Technology, vol. 67, (2014), pp. 11-22.

[6] NSCP Section 703, Mortar and Grout, National Structural Code of the Philippines, National Bookstore, (2010).

[7] T. U. Ganiron, Jr., "An empirical investigation on end-users' acceptance of compressed lahar sediment blocks as wall panel", International Journal of ICT-aided Architecture and Civil Engineering, vol. 1, no.1, (2014), pp. 19-30.

[8] ASTM C 136 - 95a, Standard Test Method for Sieve Analysis of Fine and Coarse Aggregate, Annual Book of ASTM, International Standard Worldwide, (2009).

[9] T. U. Ganiron, Jr., "An investigation of moisture performance of sawdust and banana peels ply board as non-veneer panel", International Journal of u- and e- Service, Science and Technology, vol. 6, no. 3, (2013), pp. 43-54.

[10] ASTM C 360 - 92, Standard Test Method for Ball Penetration in Freshly Mixed Hydraulic Cement Concrete, Annual Book of ASTM, International Standard Worldwide, (2009).

[11] T. U. Ganiron, Jr., "The effect of waste glass bottles as an alternative coarse aggregate in concrete mixture", International Journal of ICT-aided Architecture and Civil Engineering, vol. 1, no. 2, (2014), pp. 19-30.

[12] T. U. Ganiron Jr., "Waste tire as an asphalt cement modifier for road pavement", International Journal of u- and e- Service, Science and Technology, vol. 7, no. 5, (2014), pp. 181-194.

[13] ASTM C 143 - 90a, Standard Test Method for Slump of Hydraulic Cement Concrete, Annual Book of ASTM, International Standard Worldwide, (2009).

[14] T. U. Ganiron Jr., "Pelletized cut rubber: An alternative coarse aggregate for concrete mixture", International Journal of Advanced Science and Technology, vol. 64, (2014), pp. 21-30.

[15] T. U. Ganiron Jr., "Effect of sawdust as fine aggregate in concrete mixture for building construction", International Journal of Advanced Science and Technology, vol. 63, (2014), pp. 73-82.

[16] ASTM C 172 -90, Standard Practice for Sampling Freshly Mixed Concrete, Annual Book of ASTM, International Standard Worldwide, (2009).

[17] T. U. Ganiron Jr., "Sustainable management of waste coconut shells as aggregates in concrete mixture", Journal of Engineering Science and Technology Review, vol. 6, no. 5, (2013), pp. 7-14.

[18] T. U. Ganiron Jr., "Use of recycled glass bottles as fine aggregates in concrete mixture", International Journal of Advanced Science and Technology, vol. 61, (2013), pp. 17-28.

[19] ASTM C 109 - 80, Standard Test Method for Compressive Strength of Hydraulic Cement Mortars (Using 2-in or $50 \mathrm{~mm}$ cube specimens), Annual Book of ASTM, International Standard Worldwide, (2009).

[20] T. U. Ganiron Jr., "Analysis of fly ash cement concrete for road construction", International Journal of Advanced Science and Technology, vol. 60, (2013), pp. 33-44. 
[21] ASTM C 87, Standard Test Method for Effect of Organic Impurities in Fine Aggregate on Strength of Mortar, Annual Book of ASTM, International Standard Worldwide, (2009).

[22] T. U. Ganiron Jr., "Investigation on the use of coco coir polypropylene as thermal insulator", International Journal of Advanced Science and Technology, vol. 59, (2013), pp. 13-26.

[23] T. U. Ganiron Jr., "Effects of rice hush as substitute for rice aggregate in concrete mixture", International Journal of Advanced Science and Technology, vol. 58, (2013), pp. 29-40.

[24] NSCP Table 703-1, Mortar Proportions for Unit Masonry, National Structural Code of the Philippines, National Bookstore, (2010).

[25] T. U. Ganiron Jr., "The influence of Megatren system on ridership in Metro Manila." International Journal of u- and e- Service, Science and Technology, vol. 8, no. 1, (2015), pp. 91-104.

[26] T. U. Ganiron Jr., "Exploring the emerging impact of Metro Rail Transit (MRT-3) in Metro Manila", International Journal of Advanced Science and Technology, vol. 74, (2015), pp. 11-24.

[27] Gabriele and H. T. Townsend, "Disposal practices and management alternatives for CCA-treated wood waste", Waste Management \& Research, vol. 17, no. 5, (1999), pp. 378-389.

[28] T. U. Ganiron Jr. and M. Almarwae, "Prefabricated technology in a modular house, International", Journal of Advanced Science and Technology, vol. 73, (2014), pp. 51-74.

[29] T. U. Ganiron Jr., "Investigation on the physical properties and use of lumampao bamboo species as wood construction materials", International Journal of Advanced Science and Technology, vol. 72, (2014), pp. 49-62.

[30] T. U. Ganiron Jr., "Measuring levels of end-users' acceptance and use of UDDT", International Journal of u- and e- Service, Science and Technology, vol. 8, no. 3, (2015).

\section{Author}

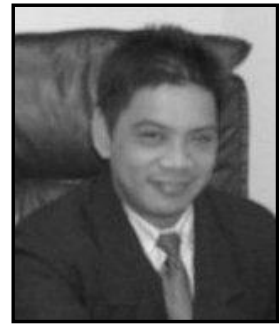

Dr. Tomas U. Ganiron Jr obtained his Doctor of Philosophy in Construction Management at Adamson University (Philippines) in 2006, and subsequently earned his Master of Civil Engineering major in Highway and Transportation Engineering at Dela Salle UniversityManila (Philippines) in 1997 and received Bachelor of Science in Civil Engineering major in Structural Engineering at University of the East (Philippines) in 1990. He is a registered Civil Engineer in the Philippines and Professional Engineer in New Zealand. His main areas of research interest are construction engineering, construction management, project management and recycled waste materials. He has been the resource person in various seminars in New Zealand (like in Auckland University of Technology, University of Auckland and University of Canterbury). He was connected with Advanced Pipeline System in New Zealand as Construction Manager wherein he supervised the sewerage and waterworks projects. He was the former Department Head of Civil Engineering in FEATI University (Manila) and former Department Head of Physics in Emilio Aguinaldo College (Manila). He is also very active in other professional groups like Railway Technical Society of Australasia and Australian Institute of Geoscientists where he became committee of Scientific Research. He has received the Outstanding Civil Engineer in the field of Education given by the Philippine Media Association Inc. (1996), ASTM Award CA Hogentogler (2008) by IPENZ in New Zealand and Outstanding Researcher (2013) in Qassim University, Buraidah City. On the second week of February 2015, Dr. Ganiron Jr. was included in the Ranking of Scientists according to Google Scholar Citation public profile (http://www.webometrics.info/en/node/81). 